Apidologie, 1987, 18 (1), 61-68

\title{
DIFFERENTIAL DRONE PRODUCTION BY AFRICANIZED AND EUROPEAN HONEY BEE COLONIES
}

\author{
Thomas E. RINDERER, Anita M. COLLINS, Richard L. HELlMICH II, \\ and Robert G. DANKA \\ with the technical collaboration of Robert SPENCER \\ United States Department of Agriculture \\ Agricultural Research Service Honey-Bee Breeding, Genetics \\ and Physiology Laboratory \\ 1157 Ben Hur Road \\ Baton Rouge, LA 70820, USA
}

\begin{abstract}
SUMMARY
The numbers of mature drones leaving colonies of Africanized and European honey bees were counted after they had been trapped at colony entrances. Two apiaries, each with 10 European and 10 Africanized colonies, were trapped for drones exiting individual colonies on 3 separate days at two week intervals. Africanized colonies maintained far more drones and far more Africanized drones parasitized European colonics than vice versa. These two factors resulted in $91 \%$ of the drones leaving colonics in the apiaries being Africanized.
\end{abstract}

\section{INTRODUCTION}

The rapid spread of Africanized ${ }^{1}$ bees and their simultaneous displacement and modification of European bees in Central and South America (recently reviewed by STiBick, 1985) present an interesting array of biological problems. Chief among them are questions concerning the mechanisms underlying the Africanization of European bee populations.

1) The European bees in this study were from North America. Such bees have mixed subspecies representatives in their ancestries. The Africanized bees are descendants of $A . m$. scutellata imports and their hybrids with various subspecies representatives previously imported to Brazil. Neither the European nor Africanized bees in this study can correctly be referred to as race, subspecies, stock, or line representatives. We use the term "geographic type » to indicate that the bees we studicd showed major characteristics typical of descriptions that have been made of temperate or tropical adapted climatically honcy bees. 
Generally, explanations of Africanization are rooted in reproductive biology. Certainly, the high swarming rate (WInston, 1980) and the high feral populations (KERR, 1971) of Africanized bees contribute to displacement. Modification is also due to mating between the two types of bees. Kerr and Bueno (1970) found a small amount of positive assortative mating between the bee types. Africanized bees must have one or several reproductive advantages to overcome such positive assortative mating.

Certainly, Africanized bees gain an important advantage when their feral populations are high. However, when Africanized feral populations are low, as is the case in the early stages of Africanization, other factors must come to bear. Otherwise, the numerical advantage of European drones should lead to the «Europeanization » of the few invading Africanized swarms.

European colonies often are invaded by Africanized swarms (Michener, 1975). This is especially true of colonies that are in some stage of queen replacement (Rinderer pers. obs.). Through this mechanism some number of colonies in European apiaries become Africanized. Drones from such Africanized colonies can then parasitize European colonies in mixed apiaries (RINDERER, et al. 1985). This parasitism leads to a decreased production of European drones in the apiary. The presence of parasitizing Africanized drones in European colonies lowers their potential to produce drones. Simultanously, the movement of Africanized drones from Africanized colonies increases their potential to produce still more drones (RINDERER, et al. 1985). Also, it may be that Africanized colonies have a greater tendency to produce drones. This study evaluates the comparative drone production of European and Africanized colonies in mixed apiaries.

\section{MATERIALS AND METHODS}

This experiment was conducted in two apiaries near Sarare in Western Venezuela. The first apiary was located in a valley devoted primarly to diversified agriculture including some wood lots of mixed native trees. The second apiary, $8 \mathrm{~km}$ distant, had a very different foraging environment. It was located at the edge of the valley and its bees had access to both the forage plants available in the agricultural valley and also to different species of plants in the less intensely farmed surrounding mountains.

The two apiaries each had ten Africanized and ten European colonies. Since "golden " (Tucker, 1985) European queens were used, the European and Africanized colonies produced drones of different colors. Thus, parasitic drones as well as the drones produced by each colony could be identified. The colonies were established as equal-sized 10 frame Langstroth units in April, 1984, before the onset of the annual rains. Throughout the rainy season the colonies were fed both sucrose solution and protein supplement with added pollen. The feeding regime was uniform for all colonies. By the time of the experiment all colonies were sufficiently large to be acceptable as honey production units; as a minimum, they all had completely occupied one Langstroth brood chamber. Several of both geographical types occupied portions of a second brood chamber

A system of trapping drones was developed to directly estimate the number of mature drones that would fly from a colony during a single afternoon and to indirectly estimate the overall drone population 


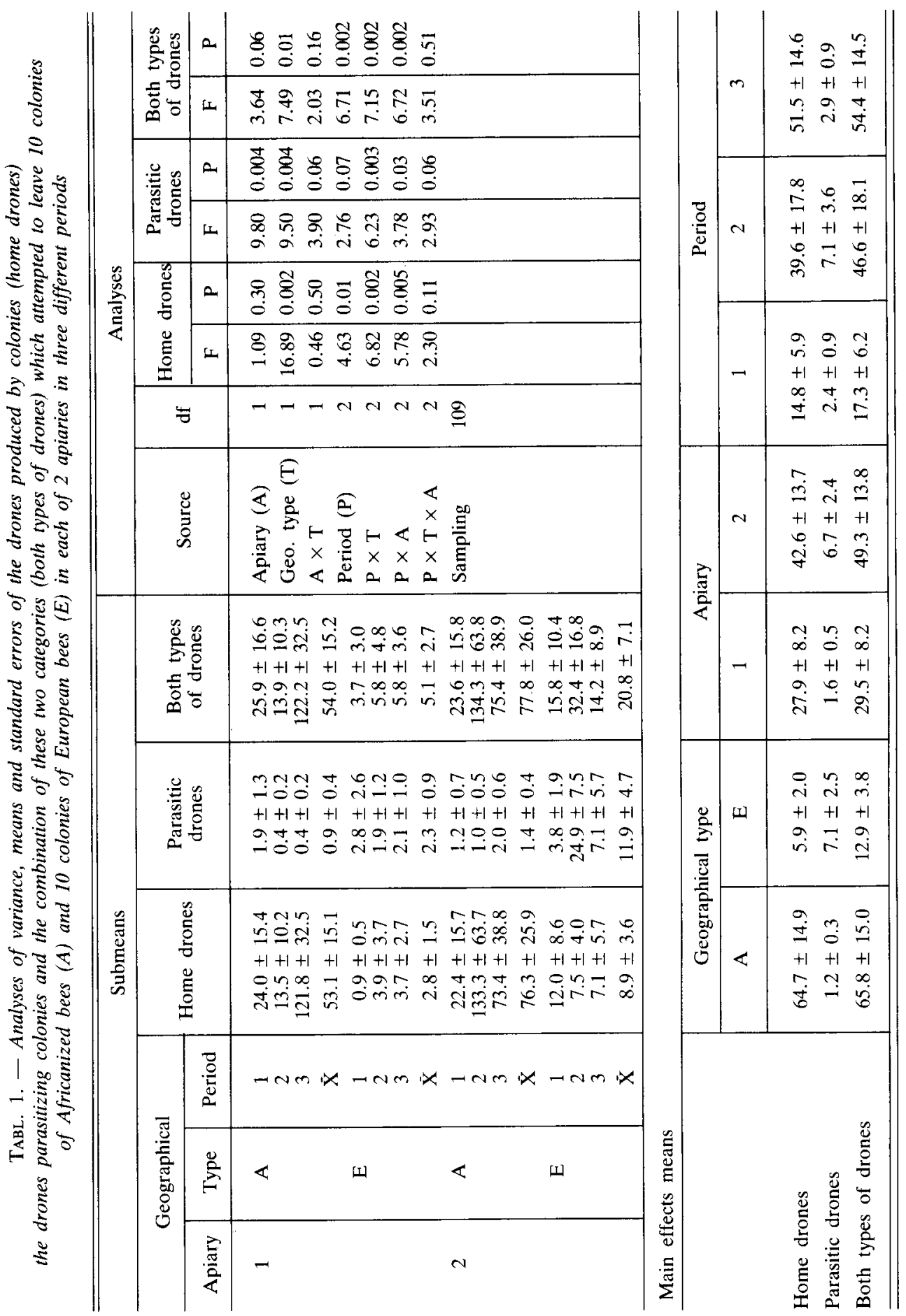


in a colony. Before trapping each hive was carefully inspected for alternate entrances, which were sealed when found. During the early morning, Alley drone traps (DaDANT, 1927) wcre placed on each colony. These traps were designed to permit normal worker-bee flight but to capture outgoing drones with a device having cones of screcn leading to areas with outside light enclosed with queen excluding materials. The following morning the traps were removed and the drones were counted. Counts were made relatively early in the favorable dry season on Oct. 15, 30 and Nov. 15, 1984.

Data were analysed by analyses of variance. The effects of apiary, geographical type of bee, trapping period, and interactions of these threc were evaluated for numbers of drones leaving colonics which produced them (home drones), numbers of parasitizing drones leaving colonies (parasitic drones) and the combination of both these types of drones.

\section{RESULTS}

The geographical types differed significantly in the number of drones leaving their colonies. Colonies of Africanized bees had an average of 66 drones leaving their hives per day while European colonies had an average of 13 (Table 1: Total drones: $\mathbf{P}=0.01$ ). Of the drones from Africanized colonies, an average of 1.2 or $2 \%$ were parasitic European drones. Of the drones from European colonies, an average of 7.1 or $55 \%$ were parasitic Africanized drones (Table 1 : Parasitic drones : $\mathrm{P}=0.004$ ). Africanized colonies contained far more drones than did European colonies $(A=65, E=6$; Table 1: Home drones: $\mathbf{P}=0.002$ ). Overall, Africanized colonies contained many more drones and the majority of drones in European colonies were Africanized. These two conditions resulted in $91 \%$ of the drones in the study being Africanized.

The two apiaries differed significantly in both the total number of drones and the number of parasitic drones leaving their colonies. Apiary 2 had more of both (Table 1: $\mathrm{P}=0.06$ and $\mathrm{P}=0.004$, respectively).

In the analysis of the number of parasitic drones, the independent variable of apiary interacted significantly with the independent variable of geographical type. The number of parasitic drones was quite low in Africanized colonies in both apiaries (Table 1 : apiary $1=0.9$; apiary $2=1.4$ ). For European colonies, the number of parasitic drones was higher in apiary 2 (Table 1: apiary $1=2.3$; apiary $2=11.9$ ). Overall, apiary 2 had more drones. However, the interaction is still apparent in calculations of parasitic drones as a percentage of the total (Africanized : $2 \%$ for both apiaries ; European : $45 \%$ and $57 \%$ for apiaries 1 and 2, respectively).

Marked significant differences occurred among periods for all three dependent variables. Also, the independent variable of period interacted significantly with both apiary and geographical type. Africanized colonies in apiary 1 had their peak drone flight activity in period 3, while in apiary 2 the peak drone activity was in period 2. Africanized and European colonies had apparently different patterns of drone production through time (Table 1). 


\section{DISCUSSION}

Overall, Africanized colonies gain a major reproductive advantage through drone production. In this experiment, over $91 \%$ of the drones were categorized as Africanized. Part of this advantage is attained by production and maintenance of larger numbers of drones in Africanized colonies. Another part is obtained by Africanized drones parasitizing European colonies. The majority $(55 \%)$ of the drones leaving European colonies were Africanized. With such numerical odds, any queen mating with the general mix of drones from such apiaries will produce primarily Africanized offspring.

Drone production seems to be primarily resource related. This is suggested both by the overall differences between apiaries and the differential response to periods between apiaries. Both apiaries had similar macroenvironmental conditions such as photoperiod, rainfall and temperature. However, their somewhat different locations did provide access to different floral resources which also varied through time. In the apparently more marginal conditions of apiary 1, Africanized colonies produced drones while European colonies produced very few. This suggests that not only do Africanized bees produce more drones but that they will produce drones, often in good numbers, in resource-scarce conditions.

Drone parasitism also seems to be influenced by resource conditions. In the apparently varying but generally better conditions of apiary 2, the general percentage of parasitism was greater. Also, when Africanized drone numbers were higher (home drones), the percentage of parasitizing Africanized drones was also higher. In period 2 of apiary 2, Africanized parasites were about $77 \%$ of the total drone population exiting from European colonies. During this period, the number of European drones slightly decreased even though the number of parasitic Africanized drones greatly increased. Thus, most of the potential drone support capacity of the European colonies was used by Africanized drones.

Such events provide Africanized bees with an important reproductive advantage. Even when Africanized bees do not have more colonies, they may be producing more drones.

Received for publication in May 1986. Accepted for publication in August 1986.

\section{ACKNOWLEDGEMENTS}

This research was conducted in cooperation with Louisiana Agricultural Experiment Station and the Universidad Centro Occidental Lisandro Alvarado, Barquisimeto, Venczucla. 


\section{RÉSUMÉ \\ DIFFÉRENCE DE PRODUCTION DE MÂLES CHEZ DES COLONIES D'ABEILLES AFRI- CANISÉES ET D'ABEILLES EUROPÉENNES (APIS MELLIFICA L.)}

L'étude a porté sur 2 ruchers comprenant chacun 10 colonies l'un d'abeilles européennes, l'autre d'abeilles africanisées. Durant 3 fois un jour à 2 semaines d'intervalle, on a piégé et compté à la sortic de la ruche les mâles qui sortaient pour des vols d'accouplement ou d'orientation.

Les colonies africanisées ont produit bcaucoup plus de mâles que les colonies européennes $(\mathrm{A}=66 \pm 15 ; E=13 \pm 4 ; \mathrm{P}=0,01)$ (Tabl. 1). Environ $2 \%$ des mâles quittant les colonies africanisées étaient des mâles européens parasites, tandis que $55 \%$ environ des mâles quittant les colonies européennes étaient des mâles africanisés parasites $(P=0,004)$. Il résulte de ces deux facteurs, production de mâles et nombre de mâles parasites, que $91 \%$ des mâles qui, dans cette étude, quittaient les colonies ćtaient des mâlcs africanisés.

\section{ZUSAMMENFASSUNG}

\section{DIFFERENZIERTE DROHNENPRODUKTION BEI AFRIKANISIERTEN UND EUROPÄISCHEN HONIGBIENEN}

Es wurden Drohnen, die zur Paarung und Orientierung aus Bienenvölkern ausfliegen wollten, in Fallen gefangen und ausgezählt.

Zwei Bienenstände mit je 10 europäischen und 10 afrikanisierten Völkern wurden dazu in zweiWochen Abständen jewcils drei Tage lang mit Drohnenfallen ausgerüstet.

Afrikanisicrte Völker produzierten weit mehr Drohnen als die curopäischen (A $=66 \pm 15$; $E=13 \pm 4 ; P=0.01$ ). Etwa $2 \%$ der Drohnen, die die afrikanisierten Völker verließen, waren parasitierende europäische Drohnen, während ca. $55 \%$ der Drohnen, dic europäische Völker verließen, parasiticrende afrikanisierte Drohnen waren $(p=0.004)$. Insgesamt ergaben die differenzierte Drohnenproduktion und der verschiedenartige Drohnenparasitismus, daß $91.22 \%$ der Drohnen in der Untersuchung afrikanisicrte waren. 


\section{REFERENCES}

DADANT C.P., 1927. - Langstroth on the hive and honey bee. 23rd ed. - The American Bce Journal, Hamilton, Illinois, 69-70.

Kerr W.E., 1971. - Contribuicao a ecogenetica de algumas especies de abelhas. Cienc. Cult. Sao Paulo, 23 (Suppl.), 89-90.

KerR W.E. and D. Bueno, 1970. - Natural crossing between Apis mellifera adansonii and Apis mellifera ligustica. Evolution, 24, 145-148.

Michener C.D., 1975. - The Brazilian bec problem. - Annu. Rev. Entomol., 20, 399-416.

Rinderer T.E., Hellmich R.L. II, Danka R.G. and A.M. Collins, 1985. - Male reproductive parasitism : A factor in the Africanization of European honey bee populations. Science, 228, 11191121.

StiBick J.N.L., 1985. - Animal and Plant Health Inspection Service strategy and the African honey bee. Bull. Entomol. Soc. Amer., 30, 22-26.

TUCKER K.W., 1986. - Visible mutants. In : Bee genetics and breeding. T.E. Rinderer, ed. - Academic Press, New York, $448 \mathrm{p}$.

WINSTON M.L., 1980. - Swarming, after swarming, and reproductive rate of unmanaged honeybee colonies (Apis mellifera). Insectes Sociaux, 27, 391-398. 